\title{
Paleobiogeography and taxonomy of the genus Concholepas (Lamarck, 1801): a review and new evidences
}

\author{
Paleobiogeografía y taxonomía del género Concholepas (Lamarck, 1801): \\ una revisión y nuevas evidencias
}

LEYLA CÁRDENAS ${ }^{1,3, *}$, FRÉDÉRIQUE VIARD ${ }^{2} \&$ JUAN CARLOS CASTILLA $^{1}$

\author{
${ }^{1}$ Center for Advanced Studies in Ecology and Biodiversity (CASEB), Facultad de Ciencias Biológicas, \\ Pontificia Universidad Católica de Chile, Chile \\ ${ }^{2}$ Equipe Evolution et Génétique des Populations Marines, LIA “DIAMS", UMR 7144 CNRS-Université Pierre et \\ Marie Curie, Station Biologique Roscoff, France \\ ${ }^{3}$ Instituto de Ecología y Evolución, Universidad Austral de Chile, Campus Isla Teja, Casilla 567, Valdivia, Chile \\ *e-mail for correspondence: leylacardenas@uach.cl
}

\begin{abstract}
The muricid gastropod Concholepas concholepas, known in Chile as 'loco', is an important component of intertidal and shallow subtidal communities, and is one of the main invertebrates targeted by small-scale fishers (divers) in Chile. Because of its ecological importance and economical value, numerous studies have been conducted to describe its life history, ecology and to understand population dynamics, fishery and management. However, little effort has been done to address the causal factor (s) behind its current geographic distribution and moreover little is known about the past distribution of the different species in the genus. In this paper, first we review the paleobiogeography, historical relationships, taxonomy and geographical distribution of Concholepas species, so to contribute in the reconstruction on the past history of the genus. Second, we discuss the robustness of using shell traits when classifying specimens of the genus Concholepas. Third, we evaluate the taxonomic status of $C$. concholepas including samples from Peru, the continental coast of Chile and Juan Fernández Archipelago, using a molecular approach. Four main conclusions are reached: (1) the evolutionary history of the genus Concholepas has been characterized by successive phenotypically different forms where the fossils species appear to be distinguishable states in the same evolving lineage; (2) the historical biogeography of Concholepas was probably the result of a southward direction process of expansions and extinctions, with the ancestral species being located in south-central Peru; (3) C. concholepas corresponds to a single taxonomic unit along its continental geographical range of distribution; (4) the mtDNA variation present in $C$. concholepas does not support the existence of the subspecies $C$. concholepas fernandizianus in the Juan Fernández Archipelago. We suggest that these results should be considered in future ecological, fishery, management and conservation studies on C. concholepas along the Peruvian and Chilean coast and in the Juan Fernández Archipelago.
\end{abstract}

Key words: paleobiogeography, southeastern Pacific coast, Concholepas, fossil record, taxonomy, mtDNA variation.

\section{RESUMEN}

El gastrópodo muricido Concholepas concholepas, conocido en Chile como 'loco', es un importante componente de comunidades marinas intermareales y submareales y es una de las principales especies de invertebrados en la pesquería artesanal chilena. Debido a su importancia y valor económico, se han realizado numerosos estudios para describir su historia de vida, ecología y entender las dinámicas poblacionales, pesquería y manejo. Sin embargo, menores esfuerzos han sido realizados para entender los factores causales detrás de su actual distribución geográfica y más aún poco es conocido acerca de la pasada distribución de las diferentes especies del género. En este trabajo, nosotros primero revisamos la paleobiogeografía, relaciones históricas y taxonomía, de las especies del género Concholepas para contribuir en la reconstrucción de la historia pasada del género. Segundo, discutimos la robustez de usar caracteres morfológicos en la taxonomía del género. Tercero, usando una aproximación molecular evaluamos el estatus taxonómico de C. concholepas incluyendo muestras desde Perú, la costa continental de Chile y del archipiélago de Juan Fernández. Se obtuvieron cuatro conclusiones principales: (1) la historia evolutiva del género Concholepas ha sido caracterizada por sucesivas formas fenotípicamente diferentes, donde las especies fósiles parecen ser estados 
morfológicos distinguibles de un único linaje evolutivo; (2) la biogeografía histórica de Concholepas parece ser resultado de un proceso continuo de expansión y extinción con dirección sur, con las especies ancestrales localizadas en el centro-sur de Perú; (3) C. concholepas corresponde a una sola unidad taxonómica a lo lago de su rango de distribución continental; (4) la variación en el ADNmt detectada en C. concholepas no apoya la existencia de la subespecie $C$. concholepas fernandizianus en el Archipiélago de Juan Fernández. Sugerimos que estos resultados deberán ser considerados en futuros estudios de ecología, pesquería, conservación y manejo en $C$. concholepas a lo largo de la costa chileno-peruana y en el archipiélago de Juan Fernández.

Palabras clave: paleobiogeografía, costa sur-este del Océano Pacífico, Concholepas, registro fósil, taxonomía, variación en el ADNmt.

\section{INTRODUCTION}

The marine gastropod Concholepas concholepas (Bruguière, 1789), is a benthic species endemic of the Southeastern Pacific coast and the only extant species of the genus Concholepas (Lamarck, 1801). At present, $C$. concholepas has a distribution ranging from tropical (Lobos Afuera Island, $6^{\circ} 27^{\prime}$ S, Stuardo 1979) to subantartic zones (Cape Horn, 56 $00^{\circ}$ S, Castilla \& Guiñez 2000), showing also a population in the Juan Fernández Archipelago $\left(33^{\circ} 36^{\prime} \mathrm{S}\right)$, distant $587 \mathrm{~km}$ from Chilean continental coastline. Due to its high economic value (Leiva \& Castilla 2002) and key ecological role in intertidal and subtidal rocky communities, this species has been intensively studied during the past two decades (Castilla \& Durán 1985, Moreno et al. 1986, Durán \& Castilla 1989, Power et al. 1996, Castilla 1999, Manríquez \& Castilla 2001, Poulin et al. 2002a). However, little effort has been done to address the causal factor (s) behind its current geographic distribution. Given its wide distribution, C. concholepas is included in all southeastern Pacific biogeographic zones as a species that crosses biogeographical barriers (Broitman et al. 2001). The modern geographical distribution of $C$. concholepas together with its local adaptations is a blending of historical and contemporary processes. Thus, its geographical distributional range is a result of a dynamic process through evolutionary time. At present, along its geographical range, $C$. concholepas is under the influence of oceanographic (e.g., Humboldt and Cape Horn) and coastal currents, climatic systems (e.g., subtropical, temperate, cold) and anthropogenic factors (Castilla 1999). Moreover, in the past the Southeastern Pacific coastal realm has experienced major environmental changes, such as intense oceanographic, climatic and geomorphologic modifications, which occurred during the Neogene (Martínez-Pardo 1990), that have shaped the present marine biogeography scenario (Camus 2001). Most probably an important part of the history of $C$. concholepas may be the result of the great spatial/temporal environmental variability along its distributional range. Therefore, in order to understand its current geographic distribution pattern, a historical approach must be considered.

Traditionally, the genus Concholepas was assigned to the muricid subfamily Thaidinae (Jousseaume, 1888) (Herm 1969, Lambiotte 1975, Stuardo 1979). However, according to the cladistic approach of Kool (1993), the genus Concholepas should be assigned to the redefined subfamily Rapaninae Gray, 1853. The Rapaninae clade comprises a large group of Eocene to contemporary predatory marine gastropods, all being prominent members of subtropical and tropical shallow-water communities (Vermeij \& Carlson 2000). Several authors have suggested that the ecological specialization and functional diversification of the rapanines occurred at times and places of high species richness and substantial ecological complexity, particularly in the post-Oligocene Indo-west Pacific region and in the tropical America during the Neogene (Vermeij 1987, Kool 1993, Vermeij \& Carlson 2000). Apparently, the specialization within the group occurred in a period characterized by a wider equatorial belt relative to the present one, when rapanines were strongly restricted by competition and predators, leading them to invade coastal refuges including the upper zones of the rocky intertidal (Vermeij 1987).

Studies of past geographical distribution of Concholepas include considerations of the taxonomy and phylogenetic relationships between the species of the genus and have 
focused on fossil specimens and definition of species based on morphological traits, such as for instance: the form and position of the spire, shell thickness, body whorl rotation and shell length/width ratios (Ponder \& Lindberg 1997). Although traditionally the gastropods classification and phylogeny are based on hardshell structure, morphological variations within species are recognized (Currey \& Hughes 1982, Janson 1982, Janson 1983, Janson \& Ward 1985). This situation often translates into serious difficulties regarding species identification, lack of confidence in systematic conclusions, generally poorly resolved phylogenetic hypotheses and unstable taxonomies (Schander \& Sundberg 2001, Collin 2003a). Hence, molecular markers have been considered as useful tools to evaluate whether morphological variations corresponds to the expression of differences related to the presence of two or more species or related to phenotypic expressions linked to environmental variation (Via \& Lande 1985, Stearns 1989, Johanesson \& Johanesson 1990, Johanesson et al. 1993, Scheiner 1993, Dalby 1997, Soler et al. 2000).

The genus Concholepas is mainly the result of extinct species, and therefore, an evaluation of its the taxonomy appears difficult. For example, for some Concholepas fossils the representation of specimens is extremely low (DeVries 2000). Collecting additional material may be prohibitive because of the rarity of the fossils, inaccessibility of the habitat or destruction of known collection localities. Besides, many of the fossil specimens available are incomplete or represented by fragmented shells and have been deposited in different museums around the world. In the past years, several taxonomical modifications on extant and fossil Concholepas species have been suggested, including the description of new species, subspecies and modifications on geographical distributions (Stuardo 1979, Kensley 1985, Vermeij 1998, DeVries 1995, 2000). Also, authors have proposed a different taxonomic status among extant populations of C. concholepas, based on characteristics of the shell, the shape of the foot and differences in the lateral teeth. For instance, taking into account the shell morphology and ornamentation among different $C$. concholepas continental populations and those from the Juan
Fernández Archipelago, Stuardo (1979) suggested the existence a subspecies in the Archipelago: C. concholepas fernandezianus. In this case, to understand biogeographic processes and patterns of speciation on $C$. concholepas would require evaluating when and how this species arrived to the Archipelago, and to follow the degree of diversification.

Attempts have been made in the coast of Chile and Perú to analyze genetic differences among $C$. concholepas populations. Guiñez et al. (1992) used isozymatic variation to study the genetic structure among 6 localities from southern Perú: Mollendo $\left(17^{\circ} 00^{\prime} \mathrm{S}\right)$, to southern Chile: Mehuín $\left(39^{\circ} 27^{\prime}\right.$ S). The authors suggested the existence of strong genetic structure and defined three genetic groups: The first represented by specimens from the northern localities: Mollendo and Iquique $\left(24^{\circ} 14^{\prime} \mathrm{S}\right)$; the second by specimens from central and northern Chile: Antofagasta $\left(23^{\circ} 41^{\prime}\right.$ S) and Coquimbo $\left(32^{\circ} 08^{\prime} \mathrm{S}\right)$, and the third by specimens form central and southern Chile: El Quisco (33 $24^{\prime}$ S) and Valdivia (39 $27^{\prime}$ S). In contrast, Gallardo \& Carrasco (1996) using the same genetic markers analyzed $C$. concholepas populations from localities in central Chile: Quintay $\left(33^{\circ} 10^{\prime} \mathrm{S}\right)$, to southern Chile: Chiloé Island $\left(42^{\circ} 38^{\prime} \mathrm{S}\right)$, and showed low levels of population subdivision and suggested the existence of genetic cohesiveness among $C$. concholepas.

An evaluation of the present taxonomy within the genus Concholepas is difficult since all the species, with the exception of $C$. concholepas, are extinct. Therefore, a molecular approach is impracticable. Nevertheless, the comparison of shell traits and molecular markers in extant populations may be useful to determinate the robustness of the morphological traits as an adequate tool to analyze the taxonomy of the genus. Also this may be useful to explore if extant populations of $C$. concholepas constitute a single taxonomic unit along its present distributional range. This is considered as a key issue linked to the management and conservation of the species. Therefore, in this paper we first attempt a comprehensive review on the taxonomy, historical relationships and geographical distribution of Concholepas species, so to contribute towards the reconstruction of the 
past history of the genus. Second, we discuss the robustness of using shell traits when classifying specimens of the genus Concholepas by comparing variations of length/width ratio and genetic diversity indexes based on sequences of mitochondrial DNA (mtDNA) in spatially distant localities inhabited by $C$. concholepas. Third, using a molecular approach, we evaluate the taxonomic status of $C$. concholepas along its present geographical range, including samples from Perú, continental Chile and the Juan Fernández Archipelago.

\section{MATERIAL AND METHODS}

Bibliographic review of the taxonomy and paleobiogeography of Concholepas

To understand the evolutionary history of the genus Concholepas, published articles on the taxonomy and geographical distribution of the genus were reviewed. Two methods were used to obtain information: (a) we followed the review made by Castilla (1988), paying particular attention to publications by Herm (1969), Beu (1970), Vokes (1972), Lambiotte (1975) and Stuardo (1979), (b) conducted a search in the ISI Web of Science database (1989 to 2006), finding 60 publications not included in Castilla (1988). Then, we selected those papers that included in their abstracts the words: fossil record, evolution, paleogeographical distribution and Concholepas.

Sample collection of extant C. concholepas

The geographical distribution of $C$. concholepas covers more than $7,000 \mathrm{~km}$ along the Southeastern Pacific coast, from $6^{\circ} \mathrm{S}$ in Peru to $56^{\circ} \mathrm{S}$, in the tip of Chile. Thus, to have a representative sampling, we collected adults or juveniles along its distributional range taken into account the biogeographical subdivision of this region proposed by Camus (2001) (Fig. 1). In the Peruvian Province (PP) we collected specimens from the subtidal in Matarani $\left(17^{\circ} 00^{\prime} \mathrm{S}, 72^{\circ} 18^{\prime} \mathrm{W}, \mathrm{n}=29\right)$; in the Intermediate Area (IA) we collected specimens from the subtidal in: El Quisco $\left(33^{\circ} 23^{\prime} \mathrm{S}\right.$, $\left.71^{\circ} 42^{\prime} \mathrm{W}, \mathrm{n}=27\right)$, and Las Cruces ( $33^{\circ} 31^{\prime} \mathrm{S}$, $\left.71^{\circ} 38^{\prime} \mathrm{W}, \mathrm{n}=27\right)$; in the Magellan Province (MP) we collected specimens from the subtidal at Puerto Aguirre $\left(45^{\circ} 15^{\prime} \mathrm{S}, 72^{\circ} 40^{\prime} \mathrm{W}, \mathrm{n}=29\right)$. In order to test for potential differences in $\mathrm{L} / \mathrm{W}$ ratio between Concholepas from intertidal and subtidal habitats we additionally collected samples from the intertidal at El Quisco ( $\mathrm{n}=$ $19)$ and Las Cruces $(n=27)$. After collections, two morphometric traits were measured in each individual: (1) total length, corresponding to the antero-posterior length measured from the border of the siphonal channel to the top of the posterior edge of the aperture, (2) total width, corresponding to the widest part of the shell when measured perpendicular to its length. Measurements were taken to the nearest 0.05 $\mathrm{mm}$ using a digital caliper. Immediately after, a piece of approximately $2 \mathrm{~cm}^{3}$ of tissue was cut from the border of the foot muscle and stored in $95 \%$ ethanol to the posterior DNA extraction. Additionally we collected foot tissue samples of $C$. concholepas specimens from Juan Fernández Archipelago (Punta Tres Reyes, $33^{\circ} 37^{\prime}$ S $-78^{\circ} 52^{\prime}$ W); however the shells were not accessible for morphometric analysis.

\section{Variation length/width ratio}

We selected the length/width ratio (L/W) as a critical Concholepas morphological trait given its common use in taxonomic studies (Herm 1969, Stuardo 1979, DeVries 1995, DeVries 2000). The $\mathrm{L} / \mathrm{W}$ ratio was calculated using two morphometric traits, total length and total width, as used in previous works (Stuardo 1979, DeVries 1995). To test for differences in L/W ratio among localities along the geographical range of distribution of $C$. concholepas we made a comparison using only subtidal specimens (Table 2). In order to test for potential differences in $\mathrm{L} / \mathrm{W}$ ratio in subtidal and intertidal environments, we used specimens collected at both habitats in Las Cruces and El Quisco. We estimated the L/W ratio expressed as the mean value and standard deviations per locality. Differences in $\mathrm{L} / \mathrm{W}$ ratio among populations were evaluated using ANOVA analysis considering the $\mathrm{L} / \mathrm{W}$ ratio as the dependent variable and locality as the grouping variable. To test for potential differences in $\mathrm{L} / \mathrm{W}$ ratio between subtidal and intertidal habitats we performed ANOVA and Tukey HSD test (Sokal \& Rohlf 1981), letting 
$\mathrm{L} / \mathrm{W}$ ratio as dependent variable and locality and habitat as grouping variable.

\section{Genetic analysis}

We used the cytochrome oxidase I mitochondrial gene (COI) because is widely used in marine species and universal primers were developed by Folmer et al. (1994). Total genomic DNA was extracted from muscle tissue using a standard phenol/chloroform protocol. The amplifications were performed as describe by Jolly et al. (2006). Double stranded PCR products were sequenced for each individual using an ABI PRISM ${ }^{\circledR} 3100$ automated DNA Sequencer (Perkin-Elmer Applied Biosystems, Foster City, California, USA). Sequences were edited and aligned using ProSeq V 2.9 (Filatov 2002) and final alignments were adjusted by eye. We performed a test introduced by Xia et al. (2003) to measure substitution saturation in a set of aligned nucleotide sequences, to evaluate whether these sequences are useful for phylogenetic analyses.

To best represent the phylogenetic relationships within $C$. concholepas, a maximum likelihood (ML) phylogenetic approach reconstruction based in the best substitution evolutionary model for the COI haplotypes was constructed. The simplest ML model that best explained the data were estimated using the Akaike Information Criterion (AIC) in the program MODELTEST 3.0 (Posada \& Crandall 1998). Additionally, bootstrap resampling (Felsenstein 1985) was applied to assess support for individual nodes using 1,000 bootstrap replicates. The gastropod Thais (Stramonita) chocolata (Duclos 1832), another Rapaninae endemic of the Southeastern Pacific was used as outgroup. The reconstruction of phylogenetic trees was performed using PAUP* software (Swofford 2002).

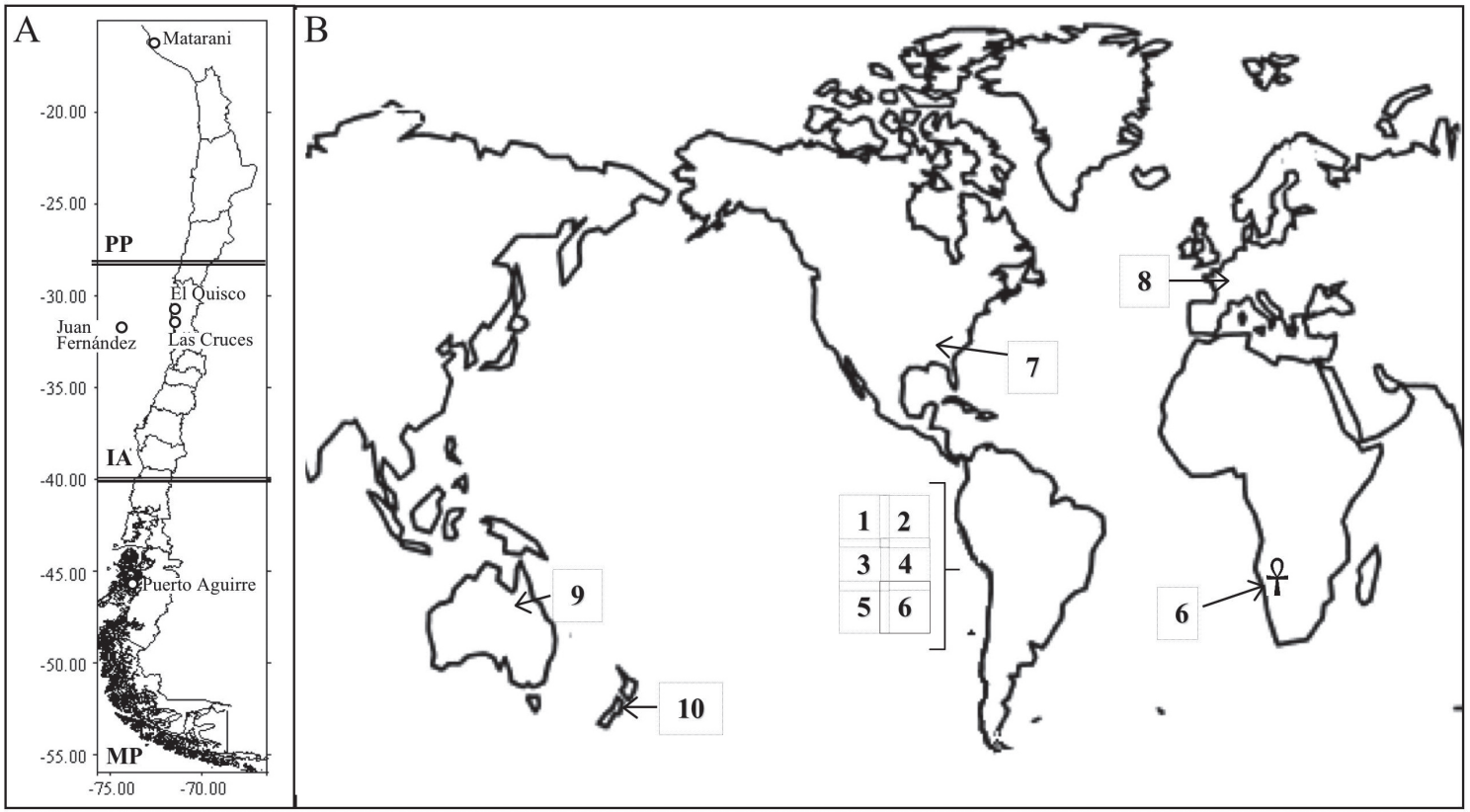

Fig. 1: Map depicting the samples localities (A) and the geographic range distribution of fossil species of the genus Concholepas (B). In (A), PP corresponds to the Peruvian Province, IA corresponds to the Intermediate Area (IA) and MP is Magallanic Province. Species in (B) are marked by numbers that correspond to table 1 .

Mapa mostrando la ubicación geográfica de las localidades muestreadas (A) y el rango geográfico de las especies fósiles del género Concholepas (B). En (A), PP es la Provincia Peruana, IA corresponde el Área Intermedia y MP representa la Provincia Magallánica. Las especies en (B) están marcadas con números que se corresponden con los de la Tabla 1. 
To analyze the genetic composition in $C$. concholepas we compared the genetic diversity among localities. The standard genetic diversity indices, such as the number of haplotypes $(\mathrm{nH})$, number of segregating sites (S), haplotype diversity $(\mathrm{He})$, the nucleotide diversity $(\pi)$ and the pairwise differences between sequences ( $\Pi)$ for each locality were estimated using Arlequin version 3.01 (Excoffier et al. 2005). Additionally, we construct a matrix of pairwise genetic differences among localities (Pairwise $\theta$, Weir \& Cockerham 1984). The significance of the pairwise $\theta$ values was tested by permutation.

\section{RESULTS}

Taxonomy and paleobiogeography of Concholepas

Since the taxonomic classification inside the Concholepas clade has been recently changed (DeVries 1995, 2000, Vermeij 1998), the geographical distribution of the genus Concholepas has suffered different interpretations according to different authors. Two main clusters may be considered in the history of this genus: a non-South American and a South American (Herm 1969, Beu 1970, Vokes 1972, Lambiotte 1975, Stuardo 1979, Kensley 1985). The non-South American clade shows a disjoint distribution (Fig. 1). However, on the basis of morphologic traits the nonSouth American species were assigned to the genus Concholepas (Herm 1969, Beu 1970, Vokes 1972, Lambiotte 1975, Stuardo 1979). All non-South American fossil species are restricted to Miocene strata. The oldest reported species of the genus is Concholepas drezi (Vokes, 1972), which dates from the late early Miocene, of the Chipola Formation in Florida, USA (Fig. 1). From the Middle Miocene, two species have been reported, Concholepas deshayesi (Rambur, 1862) from Touraine, France, and Concholepas antiquata (Tate, 1894) from Port Philip Bay and Muddy Creek, Hamilton, Australia. Finally, Concholepas pehuensis (Marwick, 1926) occurred in the late Miocene of North Taranaki, New Zealand. In addition, based on the strata type occurrence and related fauna, all Miocene species of Concholepas were associated with warmer and deeper marine environments than those experienced by modern $C$. concholepas. Moreover, Beu (1970) and Vokes (1972) suggested that the thin shell character in this non-South American clade is a signature that older species of the genus lived in environments of low wave energy; suggesting that the genus Concholepas invaded the rocky intertidal environments following the Miocene epoch. DeVries (1995), compared the species assigned to Concholepas and suggested that non-South American and South American species of Concholepas were two different and non related taxa. Vermeij (1998) re-evaluated the taxonomic position of non-South American Concholepas species, and assigned all nonSouth American species to the genus Edithais and designated $C$. drezi as the type species (Table 1). According to Vermeij (1998), the key morphological differences between both genera are: (1) Concholepas species exhibit shells with a high L/W ratio, whereas in Edithais the width exceeds the length, (2) in shells of Edithais, the spire (the posterior end of the outer lip) extends beyond the apex; while, in contrast in Concholepas, the spire extends above the adapical end of the aperture, (3) the spiral cords in Concholepas are strongly ornamented with scales and nodes, whereas those of Edithais are finer and lack axial ornaments. However, in the Vermeij \& Carlson (2000) analysis of the subspecies Rapaninae, Concholepas and Edithais appears as sister genera located at the base of the phylogenetic tree, where the phylogeny was unresolved and has low statistic support.

The South American Concholepas clade has undergone taxonomical re-arrangements and new fossil species have been described. At present the genus Concholepas is composed by six species, out of which $C$. concholepas is the only extant species (Fig. 2). The older fossil records of the species, that represents the ancestral species of Concholepas in South America, was found in Lomitas, Pisco basin (Perú), corresponding to Concholepas ungis (DeVries 1995). This species inhabited the marine realm of the early to middle Miocene (about 20.5 million years before present) and has been found only in south-central Perú (DeVries 1995). Concholepas ungis has a small shell size (not exceeding $30 \mathrm{~mm}$ in length) compared with other members of the genus. However, DeVries 


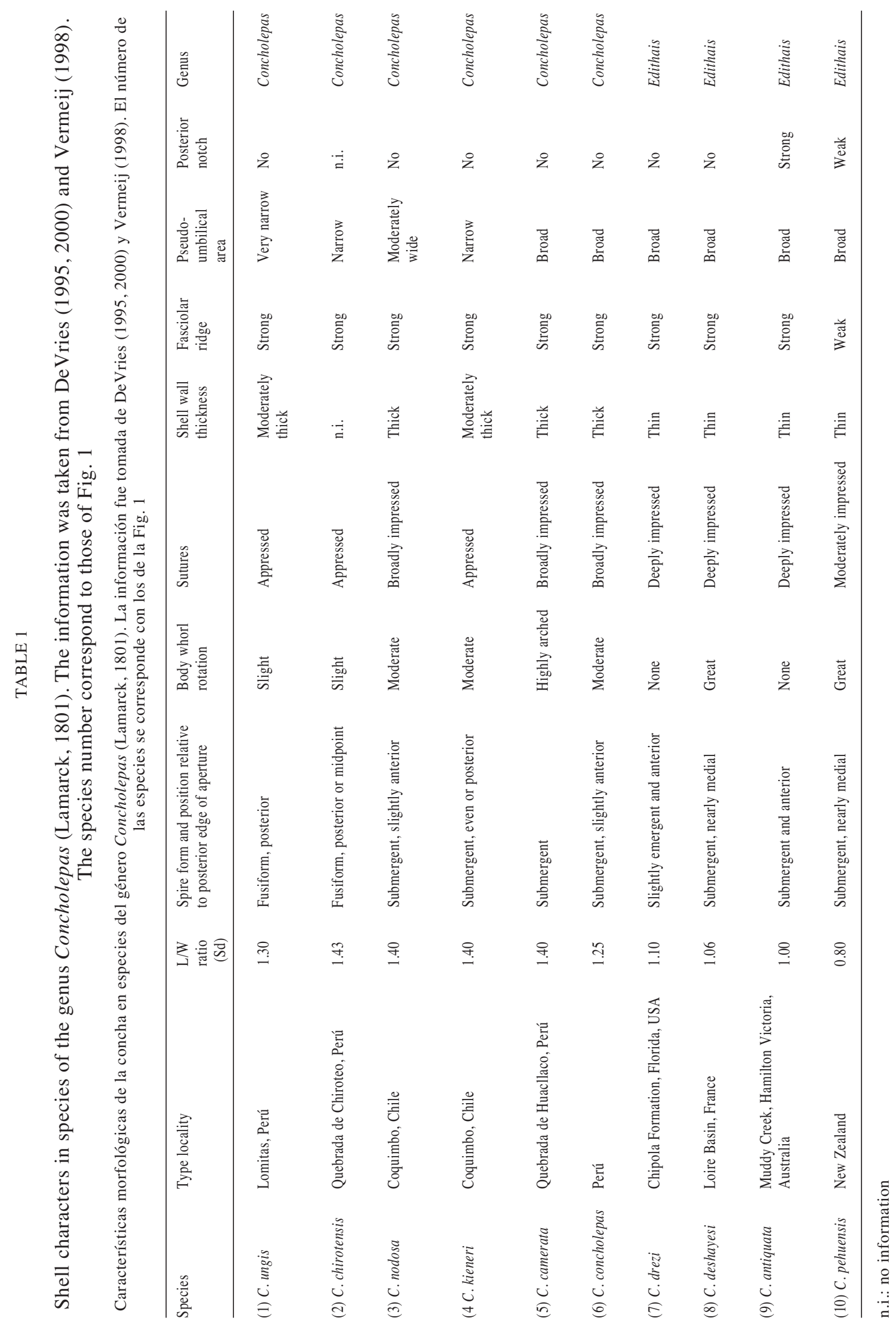




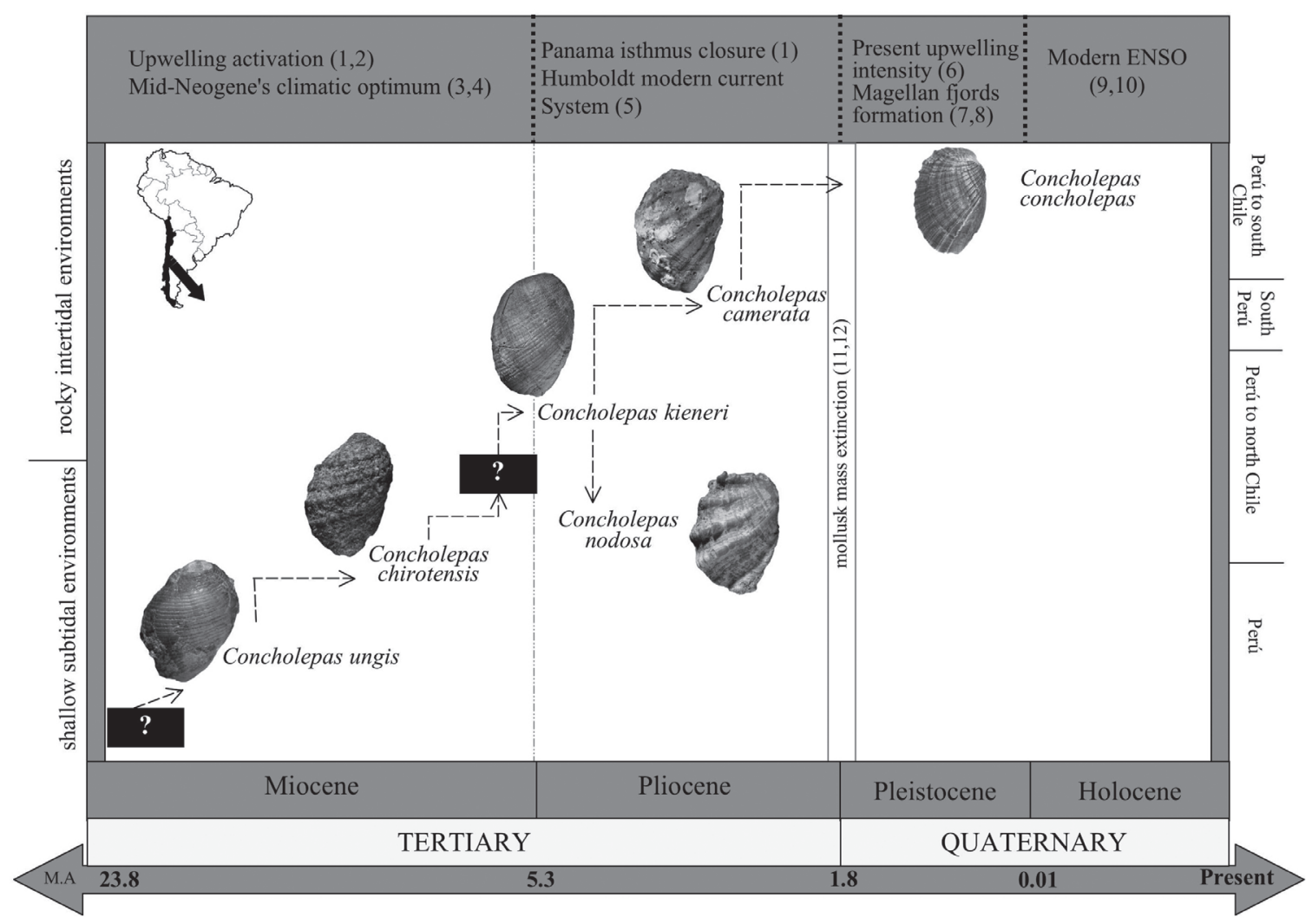

Fig. 2: Evolutionary hypotheses of Concholepas (Lamarck, 1891) in South America. The Cruz in South Africa has been referenced to the fossil record of the extant C. concholepas (see text). Pictures of fossil species were obtained from Tom DeVries collection: C. unguis USNM 447096 (holotype); C. chirotensis: USNM 447121 (paratype); C. nodosa USNM 447122; C. kieneri USNM 447088 and $C$. camerata USNM 447129 (holotype). Numbers in superior boxes correspond to follow references: (1) Zachos et al (2001); (2) Lawver \& Gahagan (2003); (3) Martinez-Pardo (1990); (4) Tsuchi (2002); (5) Zinmeister (1978); (6) OPD partnership (2002); (7) Clapperton (1994); (8) Rivadeneira (2005); (9) Moy et al. (2002); (10) Loubere et al. (2003).

Hipótesis de la evolución del género Concholepas (Lamarck, 1891) en Sudamérica. La cruz en el sur de África hace referencia al registro fósil del C. concholepas en esa área (ver texto para detalles). Fotos de las especies fósiles fueron obtenidas desde la colección del Dr. Tom DeVries: C. unguis USNM 447096 (holotype); C. chirotensis: USNM 447121 (paratype); C. nodosa USNM 447122; C. kieneri USNM 447088 and C. camerata USNM 447129 (holotype). Los números en la parte superior corresponden a las siguientes referencias: (1) Zachos et al (2001); (2) Lawver \& Gahagan (2003); (3) Martinez-Pardo (1990); (4) Tsuchi (2002); (5) Zinmeister (1978); (6) OPD partnership (2002); (7) Clapperton (1994); (8) Rivadeneira (2005); (9) Moy et al. (2002); (10) Loubere et al. (2003).

(1995) sustained that the uniformly convex body whorl, the long and broad aperture and the strong fasciolar ridge of this species represent key characters for the inclusion of this species into the genus Concholepas. Later DeVries (2000) described Concholepas chirotensis (DeVries 2000), from the end of the middle Miocene (16.4-11.2 million years before present) at Quebrada Chiroteo, in southern Perú. Apparently, these two Miocenic species were not contemporary, and both are found in depositional environments characteristic of inner shelf and shallow subtidal systems suggesting that these taxa inhabited sandy bottom environments characterized by low wave energy (DeVries 1995, 2000).

From the Pliocene epoch two fossil species are recognized: Concholepas kieneri (Hupé, 1854) and Concholepas nodosa (Möricke, 1896). These species were recognized early from the late Pliocene fossil deposit in the Coquimbo Formation, northern Chile (Herm 1969, Beu 1970, Vokes 1972). However, DeVries (1995) described new reports broadening the 
geographical distribution of both species further north into south-central Peru, up to $14^{\circ} 46^{\prime} \mathrm{S}$. These reports have also extended the temporal range of these species: $C$. kieneri ranging from the upper late Miocene to Pliocene (11.2-1.8 million years before present) and $C$. nodosa from the early Pliocene to late Pliocene (5.3-1.8 million years before present). Lately, DeVries (2000) introduced Concholepas camerata (DeVries, 2000), a species of short duration during the late Pliocene (3.6-1.8 million years before present), from the Sacaco Basin (at $14^{\circ} \mathrm{S}$ ) in southern Perú.

Regarding the extant species of the genus, the first fossil record of Concholepas concholepas was reported in late Pleistocene marine terrace deposits from northern Chile (Herm 1969, Stuardo 1979, Guzmán et al. $\left.2000^{1}\right)$. However, DeVries (1995) expanded the spatial and temporal distribution of the fossil record reporting the species from the late Pliocene to middle Pleistocene (ca 3.6-1.0 million years before present) in outcrops from the Talara Basin $\left(4^{\circ} 15^{\prime} \mathrm{S}\right.$, northernmost Perú). An outstanding paleobiogeographic feature of C. concholepas is its disjunctive distribution. In fact, Kensley (1985) recorded the species in late Pleistocene coastal deposits from west South Africa-Namibia (about $26^{\circ} \mathrm{S}$ ). According to this author, the South African $C$. concholepas fossils are indistinguishable from those in South America. Castilla \& Guiñez (2000) agreed with Kensley (1985) and suggested that the South Africa fossil shells do not differ from the approximately 8.000-9.000 years archeological shell excavated $C$. concholepas from central Chile (Jerardino et al. 1992; in 1999, J. C. Castilla analyzed shells of S. African Concholepas fossils in the Cape Town Museum of Natural History).

Variation length/width ratio on extant C. concholepas

The mean $\mathrm{L} / \mathrm{W}$ ratio for the whole data set $(\mathrm{n}=$ 158, not including Juan Fernández Archipelago samples) was $1.35 \pm 0.1$ (minimum: 1.06, maximum: 1.71). Figure 3 shows the mean L/W

1 GUZMán N, C Marquardt, L Ortlieb \& D Frassinetti (2000) La malacofauna neógena y cuaternaria del área de Caldera $\left(27-28^{\circ} \mathrm{S}\right)$ : especies y rangos bioestratigráficos. Actas of the Congreso Geológico Chileno 9: 476-481. ratio by locality. The mean $\mathrm{L} / \mathrm{W}$ ratio was significantly different among localities distributed along the geographical range distribution of $C$. concholepas $(\mathrm{F}=14.33, \mathrm{P}=$ $0.000)$. For subtidal samples $(\mathrm{n}=112$ specimens) the mean of $\mathrm{L} / \mathrm{W}$ ratio was $1.31( \pm$ 0.07 ), (maximum $=1.35$ in Puerto Aguirre and minimum $=1.25$ in Las Cruces, see details in Table 2). For the intertidal samples $(n=46$ specimens) the mean $\mathrm{L} / \mathrm{W}$ ratio was 1.39 ( \pm 0.11 ) (maximum $=1.47$ in Las Cruces and minimum $=1.36$ in El Quisco, see details in Table 2). The comparison of $\mathrm{L} / \mathrm{W}$ ratio between specimens from intertidal and subtidal environments, from Las Cruces and El Quisco, showed that there is a significant effect of habitat factor $(\mathrm{F}=95.8, \mathrm{P}=0.000)$ and the interaction term habitat*locality" $(\mathrm{F}=58.34, \mathrm{P}$ $=0.000)$ but no for locality alone $(\mathrm{F}=1.28, \mathrm{P}=$ 0.26). A Tukey HSD test showed that samples from Las Cruces intertidal are significantly higher from the other samples sites.

\section{Genetic analysis}

In total we obtained a fragment of 658 base pairs of the mitochondrial gene COI, from 179 individuals of $C$. concholepas. A total of 103 polymorphic sites and 80 haplotypes were identified. The GenBank accession numbers for these haplotypes corresponds from EU250850 to EU250929. The substitution saturation test demonstrated that our sequences have little saturation (Iss $=0.017<$ Iss $\mathrm{c}=0.719$, $\mathrm{df}=341, \mathrm{P}<0.0001)$, thus validating their use for phylogenetic inference. Results of the ModelTest showed that the most descriptive model of evolution for COI gene was $\mathrm{K} 81 \mathrm{uf}+\mathrm{I}+\mathrm{G}$ (K81 is a model with unequal base frequencies, Kimura 1981) with a proportion of invariable sites $(I=0.48)$ and gamma distribution (gamma shape $=1.31$ ). Few branches were supported by bootstrap values greater than $50 \%$ (Fig. 4) and the ML nucleotide distance among haplotypes varied between 0.15 to $1.2 \%$ (data non show). There is not a clear pattern for cluster composition of the haplotypes. In fact, all the haplotypes were distributed along the tree independently of the sampled localities. Thus, the COI mtDNA tree reconstruction suggests the existence of only one phylogenetic clade in $C$. concholepas. 


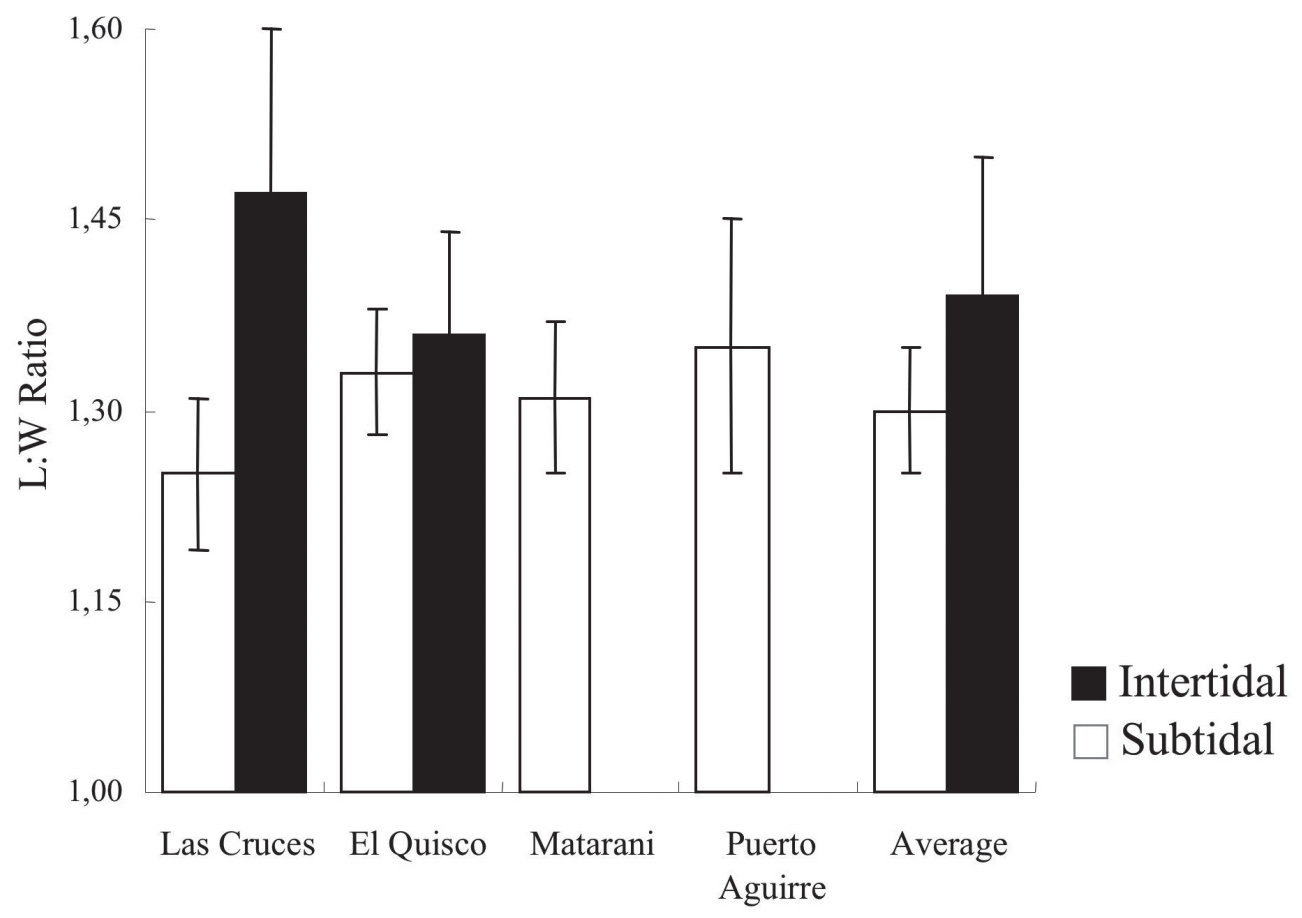

Fig.3: L/W ratio by localities and average of subtidal ad intertidal habitats.

Razón L/W por localidades y promedio de hábitat submareal e intermareal.

TABLE 2

Sampled localities of Concholepas concholepas. Mean L/W ratio, Number of samples (n), number of polymorphic sites $(\mathrm{S})$ and number of haplotypes $(\mathrm{nH})$ per locality are showed. The genotypic diversity $(\mathrm{He})$, nucleotide diversity $(\pi)$ and Mean number of pairwise differences between sequences $(\Pi)$ were calculated using Arlequin software. Standard deviations are showed in parenthesis

Localidades muestreadas para $C$. concholepas. La media de la razón L/W, el número de muestras por sitio (n), el número de sitios polimórficos $(\mathrm{S})$, y el número de haplotípos por localidad $(\mathrm{nH})$ son mostrados. La diversidad genética $(\mathrm{He})$, la diversidad nucleotídica $(\pi)$ y el número promedio entre pares de secuencias $(\mathrm{P})$ fueron calculados usando Arlequín. Desviaciones estándar son mostradas en paréntesis

\begin{tabular}{|c|c|c|c|c|c|c|c|c|}
\hline Habitat & Locality & L/W Ratio $( \pm \mathrm{SD})$ & $\mathrm{n}$ & S & $\mathrm{nH}$ & $\mathrm{He}( \pm \mathrm{SD})$ & $\pi( \pm \mathrm{SD})$ & $\Pi( \pm \mathrm{SD})$ \\
\hline \multirow[t]{3}{*}{ Intertidal } & Las Cruces & $1.47( \pm 0.13)$ & 27 & 32 & 22 & $0.96( \pm 0.03)$ & $0.004( \pm 0.002)$ & $2.64( \pm 1.45)$ \\
\hline & El Quisco & $1.36( \pm 0.08)$ & 19 & 15 & 11 & $0.83( \pm 0.09)$ & $0.003( \pm 0.002)$ & $1.77( \pm 1.07)$ \\
\hline & Total & $1.39( \pm 0.11)$ & 46 & 42 & 35 & $0.91( \pm 0.04)$ & $0.004( \pm 0.002)$ & $2.20( \pm 1.26)$ \\
\hline \multirow[t]{6}{*}{ Subtidal } & Las Cruces & $1.25( \pm 006)$ & 27 & 33 & 23 & $0.94( \pm 0.04)$ & $0.005( \pm 0.003)$ & $3.19( \pm 1.70)$ \\
\hline & El Quisco & $1.33( \pm 0.05)$ & 27 & 24 & 14 & $0.80( \pm 0.08)$ & $0.003( \pm 0.002)$ & $2.03( \pm 1.18)$ \\
\hline & Matarani & $1.31( \pm 0.06)$ & 29 & 22 & 18 & $0.86( \pm 0.06)$ & $0.003( \pm 0.002)$ & $2.01( \pm 1.16)$ \\
\hline & Puerto Aguirre & $1.35( \pm 0.10)$ & 29 & 25 & 19 & $0.86( \pm 0.06)$ & $0.003( \pm 0.002)$ & $2.23( \pm 1.27)$ \\
\hline & Juan Fernández & n.i. & 21 & 20 & 16 & $0.97( \pm 0.02)$ & $0.04( \pm 0.003)$ & $2.99( \pm 1.62)$ \\
\hline & Total & $1.30( \pm 0.05)$ & 133 & 85 & 80 & $0.89( \pm 0.04)$ & $0.004( \pm 0.002)$ & $2.49( \pm 1.38)$ \\
\hline
\end{tabular}

n.i.; no information 


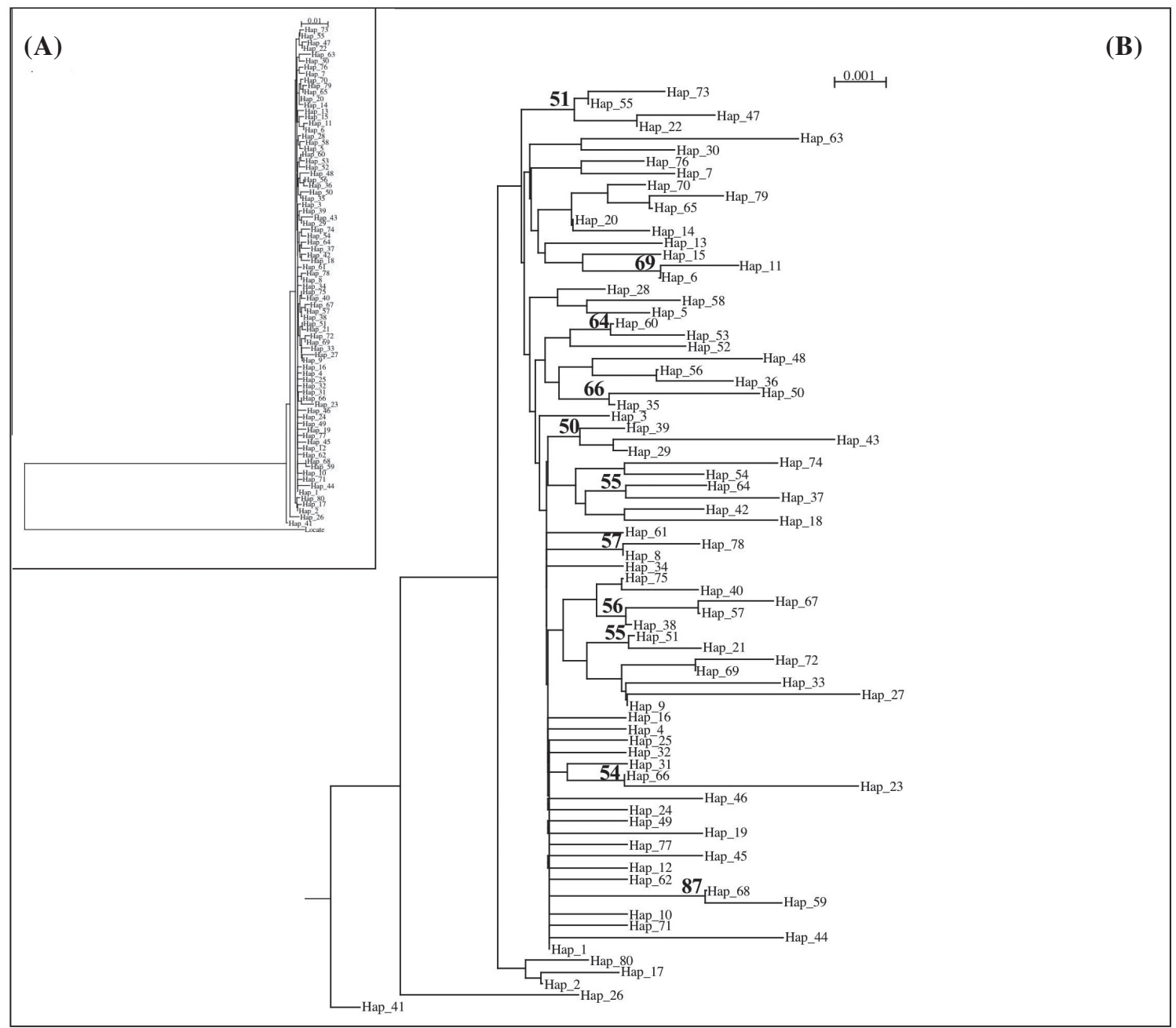

Fig.4: Maximum Likelihood tree among the COI haplotypes of Concholepas concholepas; (A) phylogram, and (B) subtree showing the relations inside the in-group. Values above each branch indicate the bootstrap percentages (> $50 \%, 1,000$ replicates) for the ML analysis.

Árbol de Máxima Verosimilitud entre los haplotipos del gen COI en C. concholepas; (A) filograma y (B) subárbol mostrado las relaciones dentro del grupo. Valores sobre ramas indican el porcentaje de "bootstrap" (> 50\%, 1.000 réplicas).

The genetic analyses inside the clade showed a general pattern of high level of polymorphism and low genetic structure in the sampled localities. For example, the comparison among localities showed high level of genetic polymorphism (Table 2). While, the nucleotide diversity was low and the mean number of pairwise differences between sequences ranged from 1.77 in Quisco subtidal to 2.99 in Juan Fernandez samples (Table 2).

The subtidal and intertidal habitats were compared using samples from Las Cruces and
El Quisco. No differences in gene and nucleotide diversity between subtidal and intertidal samples were found (Student ttests; $\mathrm{P}=0.88$ and $\mathrm{P}=0.55$ ). Low pairwise $\theta$ st values were found among all sampled localities. Only 3 of 21 comparisons resulted significant at $5 \%$ level. Here, Juan Fernandez Archipelago appears to be genetically different from Las Cruces intertidal, Quisco Intertidal and Matarani (Table 3). However, non-significant $\phi$ st pairwise comparisons were detected after Bonferroni correction (Table 3). 


\section{DISCUSSION}

Taxonomy and paleobiogeography of Concholepas

Based on this literature review, we postulated that the evolutionary pattern in Concholepas appears to represent a chronospecies (Fig. 2), receiving different names for the successive phenotypically forms, and where the fossils species appear to be distinguishable states along the evolving lineage (Stanley 1978). Therefore, we postulated that the term morphospecies may be more appropriate to refer to the fossil species of the genera Concholepas. Evidences to support the above statements are: (1) the endemic character of the genus, which has been present only in the southeastern Pacific coast. Deposits from the Navidad Formation $\left(32^{\circ} 30^{\prime}-34^{\circ} 00^{\prime} \mathrm{S}\right)$, one of the most extensively studied onshore unit in Chile and considered as a reference for the marine Neogene of the Chilean coast (Frassinetti \& Covacevich 1981, 1982, DeVries \& Frassinetti 2003, Groves \& Nielsen 2003, Nielsen 2004, 2005) has not yield specimens of the genus Concholepas. Therefore, only the most recent species, C. concholepas, appears to have a wide extension along the Southeastern Pacific coast. (2) During its evolutionary history the genus Concholepas gradually changed from shallow subtidal environments to more exposed wave energy ones (i.e., rocky intertidal). The fossil records show that along these transitions (Fig. 2), a series of morphospecies occurred sequentially. During the Pliocene epoch there were two coexisting species: $C$. kieneri and $C$. nodosa, which may be considered as a single radiation event in this genus. (3) Lastly, transitional states of morphologically different lineages in the genus have been recently identified: $C$. chirotensis and $C$. camerata. Both species appear to have had short lived period (DeVries 2000) and were extant during the transition of MiocenePliocene and Pliocene-Pleistocene, respectively.

Following these perspectives, the evolution of Concholepas apparently responded to environmental changes that occurred in the southeastern Pacific coast associated with the consolidation of the upwelling-Humboldt current system. The first change in Concholepas lineage may have occurred during the late Middle Miocene (about 15-12 million years before present), associated to a cooling period due to the gradual decline of surface seawater temperature and upwelling activation in the Peruvian coast (Ibaraki 1997). According to the fossil record, Concholepas ungis was then extinct, while Concholepas chirotensis appeared around the late Middle Miocene

TABLE 3

Pairwise $\phi$ st comparison between $C$. concholepas localities (below diagonal); (*) significant $\mathrm{P}$ values at $\alpha=0.05$ (above diagonal). Only non significant values were obtained after Bonferroni correction for multiple tests

Comparación de $\phi s t$ entre pares de localidades muestreadas (bajo de la diagonal); (*) valores de probabilidad significativos a $\alpha=0,05$ (sobre la diagonal). No se encontraron valores significativos de diferenciación después de una corrección de Bonferroni para pruebas múltiples

\begin{tabular}{lccccccc}
\hline & 1 & 2 & 3 & 4 & 5 & 6 & 7 \\
\hline 1. Matarani & - & 0.431 & 0.092 & 0.105 & $0.039 *$ & 0.350 & 0.378 \\
2. Quisco subtidal & -0.0001 & - & 0.321 & 0.441 & 0.076 & 0.686 & 0.698 \\
3. Las Cruces subtidal & 0.0084 & 0.0034 & - & 0.342 & 0.056 & 0.477 & 0.569 \\
4. Puerto Aguirre & 0.0092 & 0.0005 & 0.0019 & - & 0.102 & 0.518 & 0.626 \\
5. Juan Fernández & 0.0201 & 0.0165 & 0.0173 & 0.0140 & - & $0.042 *$ & $0.026 *$ \\
6. Quisco intertidal & 0.0025 & -0.0047 & -0.0006 & -0.0020 & 0.02791 & - & 0.883 \\
7. Las Cruces intertidal & 0.0004 & -0.0024 & -0.0004 & -0.0023 & 0.0221 & -0.0071 & - \\
\hline
\end{tabular}


(DeVries 2000). However, this morphospecies appears to have had a short-lived period and was limited to southern Perú (fossils have been registered around $16^{\circ} \mathrm{S}$ ). In fact, in accordance with DeVries (2000), there is a gap in the transition from $C$. chirotensis to $C$. kieneri and their phylogenetic relationship remains unclear (Fig. 2). From Miocene to Pliocene, the genus Concholepas began to expand southward: Concholepas kieneri and in upper Late Miocene inhabited the coast of southern Perú. During the Pliocene (3.6-1.8 million years before present), $C$. kieneri reached the northern coast of Chile, following the evolution of the oceanographic system along the southeastern Pacific (Jacobs 2004). During the Pliocene, the closing of the Panama seaway, as well as the consolidation of the modern Humboldt Current system and the expansion of coastal upwelling in the Pacific, took place (Zinmeister 1978, Ortlieb 1995, Villagrán 1995, Ibaraki 1997, Zachos et al. 2001, Nishimura 2002, Tsuchi 2002). During the Pliocene epoch two species of Concholepas co-occurred along the southeastern Pacific coast (Fig. 2). The macroenvironmental variations may have increased the diversity of coastal environmental conditions and caused an upsurge in the mollusk speciation processes. For instance, forcing the most primitive Concholepas forms (C. kieneri) to split into two branches, and one of them may have derived into the morphospecies Concholepas nodosa (Fig. 2); while the other remained unchanged. During this epoch, C. kieneri and C. nodosa appeared in the fossil record as sympatric species with a similar geographical distribution from southern Perú to northern Chile; and, as suggested by the fossil record during this period, the genus may have expanded to more exposed coastal habitats.

The transition from the Pliocene to the Pleistocene was marked by mass extinction of mollusks in the Peruvian and northern Chile coasts (Herm 1969, Vermeij 1987, DeVries 2001, Rivadeneira 2005). The development of hypoxic conditions imposed by a shallow oxygen minimum zone as a consequence of the Neogene onset of coastal upwelling in the Peruvian Province has been hypothesized to be the responsible mechanism for the Pliocene mollusk mass extinction in this area. The effect of this extinction in the Peruvian and northern
Chile coasts has been recently reviewed for the marine bivalve species (Rivadeneira 2005). This author proposed a model where the onset of the Humboldt Upwelling System acted as a double-edge sword, devastating marine diversity on one side and promoting the increase in abundance of the remaining forms on the other. It is likely that these events may have promoted the extinction of $C$. kieneri and C. nodosa. At the same time, Concholepas camerata appeared in southern Perú (about $15^{\circ}$ S), representing a short-lived morphospecies. The short history of this morphospecies may also be connected with the massive mollusk extinctions in the Peruvian Province during the Pliocene-Pleistocene boundary, since the fossil records show up that $70 \%$ of mollusk the species went extinct during these events (Herm 1969, DeVries 20012). Thus, during the Pleistocene only one species of Concholepas is found in the fossil record: Concholepas concholepas.

The existence of African fossils of $C$. concholepas in the Pleistocene (Kensley 1985) stresses the importance of Concholepas dispersal potential on the evolutionary history of the species, and may explain the present wide geographical range extension of the species in South America. According to Kensley (1985) the African fossils of $C$. concholepas may represent a founding and pioneer population that settled on the rocky intertidal of South Africa-Namibia, following drifting larvae transported via the West Wind Drift from southern South America to the west. Castilla \& Guiñez (2000) suggested that the fossil record of $C$. concholepas present in South Africa-Namibia, may have originated from juvenile/adult groups of Concholepas arriving to the west African coast on consolidated drifting substrata, as a case of kelp-rafting across oceanic routes (e.g., O O'Foighil et al. 1999, Thiel \& Haye 2006). A breeding population of $C$. concholepas may have established in these coasts, but went later extinct due to either fluctuation in sea level, limited reproductive potential of a small local population, or by the negative consequences of

DEVRIES TJ (2001) Contrasting patterns of Pliocene and Pleistocene extinctions of marine mollusks in western North and South America. Geological Society of America, Abstract A-35. 
a strong founder effect. The long distance dispersal via rafting has been used to explain the presence of closed related phylogenetic clade in opposite marine coastal margins. For example, the calyptraeid limpet, Bostrycapulus cf. aculenta sp.1 (Collin 2003b), a direct developer, inhabits both the east coast of South America and South Africa. Molecular data have shown that the South African population has recently derived from the South American population, an event that may have occurred by trans-Atlantic-rafting (Collin 2003b). Moreover, recent phylogeographic studies of southern marine taxa (e.g., Diloma and Parvulastra) imply that passive rafting cannot be ignored as an important mechanism for long-distance dispersal (Donald et al. 2005, Waters et al. 2007).

Two ecological aspects of $C$. concholepas could be the most important elements to determine its long distance dispersal: (a) the characteristics of the planktonic larvae; (b) the trophic ecology of $C$. concholepas. Briefly,

C. concholepas is gonochoric but lacks sexual dimorphism (Castilla 1983). Females lay egg capsules on low intertidal and shallow subtidal rocky surfaces (Castilla 1979, Manríquez \& Castilla 2001). After approximately 1 month of intracapsular development, small planktotrophic veliger larvae are released and spend at least 3 months in the water column (DiSalvo 1988, but see Molinet et al. 2005). Once the larvae become competent, they dwell at the sea surface until they settle on rocky intertidal and shallow subtidal habitats (Stotz et al. 1991, Moreno et al. 1993, Martínez \& Navarrete 2002). The Concholepas larval duration in the plankton suggest a high potential for dispersal. However, Poulin et al. (2002b) reported a vertical migration mechanism for Concholepas larvae to avoid their offshore dispersal. On other hand, $C$. concholepas is a carnivore, slow moving muricid, preying predominantly on mussels, barnacles and ascidians (DuBois et al. 1980). Additionally, it has been demonstrated that barnacles induce settlement behavior and metamorphosis of competent larvae (Manríquez et al. 2004), suggesting that larvae of $C$. concholepas respond to chemical cues originated from their most preferred prey (Stotz et al. 2003). There are evidences for the recruitment and establishment of juvenile of
Concholepas, mussels, barnacles and ascidians inside the holdfast of kelps (Cancino \& Santelices 1984, Vásquez \& Santelices 1984). Thus, newly settled individuals of Concholepas inside these holdfasts could encounter a permanent solid substrate and abundant prey items (mussels, barnacles, ascidians, etc.). Thus the rafting by kelps may be a probably mechanism for long distance dispersal in $C$. concholepas.

\section{Morphologic and genetic diversity in extant populations of $\mathrm{C}$. concholepas}

The L/W ratio was used to describe the range of morphological variation along the geographical distribution of the extant $C$. concholepas (more than $7,000 \mathrm{~km}$ of coast line and oceanic islands). Our analysis showed that there is much more variation on $\mathrm{L} / \mathrm{W}$ ratio than reported by DeVries (1995) and Vermeij (1998) and interestingly, this range of variation incorporates all variation detected in the studied fossil species. For instance, the minimum value of $\mathrm{L} / \mathrm{W}$ ratio for $C$. concholepas detected in our analysis was 1.06 , the same value reported for Edithais deshayesi by DeVries (1995) (Table 1). Moreover, in this regards the literature contains contradictory information. DeVries (1995) reported for Pleistocene specimens of $C$. concholepas an average L/W ratio of 1.25 (Table 1), which can be compared with the mean value of $1.35 \pm 0.1$ for the whole data set reported in our analysis (Table 2). Considering the variation in $\mathrm{L} / \mathrm{W}$ ratio detected among extant $C$. concholepas (Fig 3), the usefulness of this character for taxonomic studies remains ambiguous. In fact, spatial variation in L/W ratio detected here may reflect phenotypic plasticity associated with hydrodynamics stress or other environmental cues (e.g., Palmer 1985, 1990, Trussell 1997). For instance, several ecological factors are known to influence shell shape in mussels (Brown et al. 1976, Richardson \& Seed 1990), oysters (Chinzei et al. 1982), clams (Cigarria \& Fernández 1998) and tunicates (Paine \& Suchanek 1983). Our results confirm that the shell morphology could be highly variable to be used in taxonomic issues, and the differentiation in $\mathrm{L} / \mathrm{W}$ ratio among extant $C$. concholepas probably corresponds to particular growth conditions (differences between 
intertidal versus subtidal), or perhaps is due to different hydrodynamics patterns along its range distribution. This differentiation of $\mathrm{L} / \mathrm{W}$ ratio has been reported in patellogastropod limpets and some authors have suggested that is caused by tidal level, desiccation stress or water turbulence (Ino 1935, Segal 1956, Vermeij 1973, Simpson 1985). These results are in conflict with a previous analysis by Stuardo (1979), who gives to this morphologic variability a taxonomic character. In fact, based mainly on analysis of these characters, he proposed the existence of a subspecies in the Juan Fernández archipelago: Concholepas concholepas fernandizianus.

Two important results upsurge from our genetic analysis of the COI sequences in $C$. concholepas. First, the ML tree of the COI haplotypes of $C$. concholepas from five localities spatially separated along its range distribution, suggests that a single mitochondrial clade is present along the whole southeastern Pacific coast (Fig. 4). Second, the low level of genetic differentiation among localities does not support the existence of the subspecies $C$. concholepas fernandizianus (Table 3).

A low level of genetic differentiation was detected among all sampled sites (non significant pairwise $\phi s \mathrm{~T}$ values and non significant differences in gene diversity indices). These results agree with Gallardo \& Carrasco (1996), suggesting genetic cohesiveness among localities from the central-south geographic distributional range of $C$. concholepas. On the other hand, our study is in disagreement with the conclusions reached by Guiñez et al. (1992), whom postulated the existence of at least two genetically structured clusters: a northern ChilePerú and a center-northern Chile cluster. Differences in the molecular markers used by previous mentioned authors have prevented us the comparison among our results and the former ones. Guiñez et al. (1992) and Gallardo \& Carrasco (1996) used isozymes and these markers unmask primarily the genetic changes in coding regions that posses altered amino acid sequences; then the effect of selection on isozymes markers cannot be totally discarded. A mechanism of temporal variation in genetic differentiation mediated by selection could explain the contradictions between Gallardo \& Carrasco (1996) and Guiñez et al. (1992). El Niño event is the most important perturbation in the northern part of the range distribution of C. concholepas. Could it be that the population structure detected by Guiñez et al. (1992) actually reflected the consequences of those events on the genetic structure of $C$. concholepas? The strong effect of the El Niño events on the genetic structure of the marine species has been reported in this area (for example for the brow algae Lessonia nigrescens; Martínez et al. 2003). In our study we detected no genetic differentiation among spatially separated localities. For example, in spite that Matarani (in Perú) and Puerto Aguirre (south of Chile) are separated by more than $3,000 \mathrm{~km}$, the genetic divergence between those populations was only $0.9 \%$ (Table 3 ). This pattern has been reported in other marine species (Uthicke \& Benzie 2003, Cassone \& Boulding 2006, Zane et al. 2006). Two genetic patterns could explain the reported apparent homogeneity in the sampled localities of $C$. concholepas: (a) broad scale homogeneity, (b) chaotic genetic patchiness (Hellberg et al. 2002). The broad scale homogeneity is a pattern likely due to high levels of gene flow, which is typically found in marine species with planktotrophic larvae. On the other hand, if adults' populations of a marine species show low levels of genetic subdivision and if repeated sampling of recruits from the same locality over time reveals a high genetic differentiation among different cohorts, one would expect a chaotic genetic patchiness pattern. In C. concholepas, as in other marine gastropods, random recruitments could favor the broad genetic homogeneity pattern (Hellberg et al. 2002). However, reproductive success has been shown to vary considerably among individuals of marine benthic invertebrates showing planktonic larval phase (Grange 2005). Thus, only a small portion of the individuals may contribute to the next generation, a process resulting into important temporal genetic changes, known as the "sweepstake hypothesis" (Hedgecock 1994). Thus, the sweepstake hypothesis may be behind the present genetic homogeneity observed in the localities where Concholepas was sampled and consequently a future temporal study of the genetic variability may be an important next step to determine the role of the temporal environmental changes and their effect in the genetic structure of $C$. concholepas. 
Non-significant genetic differentiation was detected among continental samples of $C$. concholepas and the subspecies $C$. concholepas fernandizianus. The genetic divergence from the $\phi$ sT comparison (Table 3) among the subspecies of Juan Fernández archipelago and the continental samples of $C$. concholepas was estimated at $c a .1 \%$, and it does not differ from the divergences detected among continental sampled localities of $C$. concholepas. These results suggest a recent arrival of $C$. concholepas to the Juan Fernández Archipelago. However, the present level of connectivity among insular and continental populations of $C$. concholepas is unknown. Based on high degree of endemism in Juan Fernández, authors have suggested the existence of limited species exchange across the northward flow of the Chile-Perú current system (Andrade 1985, Pequeño \& Saez 2000). Nevertheless, it has also been suggested the existence of other mechanisms for biological arrivals to the archipelago form the continent; for instance, via the rock lobster fishing boats moving between the archipelago and the continent, or even the transport of specimens via air planes, or alternatively due to ENSO events of such intensity so as to reach the archipelago (e.g., Silva \& Sievers 1973, Arana 1987). Further studies are needed to evaluate if a contemporary connection between Juan Fernández archipelago and continental populations of $C$. concholepas exists, and if this has occurred due to Concholepas high larval dispersal, rafting drift and/ or oceanic currents, or if it has happened mediated by accidental or on purpose human transport.

The studies on causal factors of the present biogeography pattern of marine invertebrate along the southeastern Pacific coast are just beginning. One important component of these studies, is to learn about the past history of the species, which it will probably related to historical process modulating the present level of biodiversity either between or within species. The evolutionary history of Concholepas genus could be characterized as a unique evolutionary lineage which continuously was modifying its morphology, evolved to new environments and recently reached a wide distribution along of the Southeastern Pacific coast coast. Moreover, the only extant species of the genus corresponds to a single taxonomic unit including Juan Fernández Archipelago populations. Few studies have compared different localities along the distributional range of $C$. concholepas. Finally, further studies are necessary to clarify the current level of connectivity among Concholepas concholepas populations, the present level of diversification among continental and insular C. concholepas populations and the possible impact of fisheries in the genetic diversity of the natural and overexploited populations of $C$. concholepas.

\section{ACKNOWLEDGMENTS}

We are very grateful to Elie Poulin (Universidad de Chile) Alejandro Perez (Oceana Foundation) and Patricio Manriquez (Universidad Austral de Chile) for providing tissue samples of $C$. concholepas from Juan Fernández Archipelago. We also sincerely thank Dr. Tom DeVries, who generously provided photographs of Concholepas fossil species and for insightful comments and suggestions to improve the manuscript. This study was funded by grants awarded by ECOS $\mathrm{N}^{\circ} \mathrm{C} 03 \mathrm{~B} 04$ and FONDAP-FONDECYT 15010001 Program 6 to the CASEB. L. Cárdenas acknowledges a doctoral fellowship from CONICYT-Chile and a grant from CNRS and UPMC for travel and stay in France as part of her co-supervised doctoral thesis. This work is part of the "Program 1: Biogeography: transition zones and range limits" of LIA DIAMS.

\section{LITERATURE CITED}

ANDRADE H (1985) Crustáceos decápodos marinos del Archipiélago de Juan Fernández. In: Arana P (ed) Investigaciones marinas en el archipiélago de Juan Fernández: 109-116. Escuela de Ciencias del Mar, Universidad Católica de Valparaíso, Valparaíso, Chile.

ARANA P (1987) Perspectivas históricas y proyecciones de la actividad pesquera realizada en el archipiélago de Juan Fernández, Chile. In: Castilla JC (ed) Islas oceánicas chilenas: conocimiento científico y necesidades de investigación: 319-353. Ediciones Universidad Católica de Chile, Santiago, Chile.

BEU AG (1970) Taxonomic position of Lippistes pehuensis Marwick, with a review of the species of Concholepas (Gastropoda: Muricidae). Journal of the Malacological Society of Australia 2: 39-46.

BROITMAN BR, SA NAVARRETE, F SMITH \& SD 
GAINES (2001) Geographic variation of southeastern Pacific intertidal communities. Marine Ecology Progress Series 224: 21-34.

BROWN RA, R SEED \& J O'CONNOR (1976) A comparison of relative growth in Cerastoderma (= Cardium) edule, Modiolus modiolus, and Mytilus edulis (Mollusca: Bivalvia). Journal of Zoology (London) 179: 297-315

CAMUS PA (2001) Biogeografía marina de Chile continental. Revista Chilena de Historia Natural 74: $587-617$

CANCINO J \& B SANTELICES (1984) Importancia ecológica de los discos adhesivos de Lessonia nigrescens Bory (Phaeophyta) en Chile central. Revista Chilena de Historia Natural 56: 23-33.

CASTILLA JC (1979) Concholepas concholepas (Mollusca: Gastropoda: Muricidae): posturas de cápsulas en el laboratorio y la naturaleza. Biología Pesquera (Chile) 12: 91-97

CASTILLA JC (1983) E1 recurso Concholepas concholepas $\mathrm{Su}$ biología y estado en que se encuentra la pesquería en Chile. In: Parana (eds) Análisis de pesquería chilenas: 37-51. Universidad Católica de Valparaíso, Valparaíso, Chile.

CASTILLA JC (1988) Una revisión bibliográfica (19801988) sobre Concholepas concholepas (Brugière, 1789) (Gastropod: Muricidae): problemas pesqueros y experiencia en repoblación. Biología Pesquera (Chile) 17: 9-19.

CASTILLA JC (1999) Coastal marine communities: trends and perspectives from human-exclusion experiments. Trends in Ecology and Evolution 14: 280-284.

CASTILLA JC \& LR DURÁN (1985) Human exclusion from the rocky intertidal zone of central Chile: the effects on Concholepas concholepas (Gastropoda). Oikos 45: 391-399.

CASTILLA JC \& R GUIÑEZ (2000) Disjoint geographical distribution of intertidal and nearshore benthic invertebrates in the southern hemisphere. Revista Chilena de Historia Natural 73: 585-603.

CASSONE BJ \& EG BOULDING (2006) Genetic structure and phylogeography of the lined shore crab, Pachygrapsus crassipes, along the northeastern and western Pacific coasts. Marine Biology 149: 213 226.

CIGARRIA J \& J FERNÁNDEZ (1998) Manila clam (Ruditapes philippinarum) culture in oyster bag: influence of density on survival, growth and biometric relationships. Journal of the Marine Biological Association of the United Kingdom 78: $551-560$

CHINZEI K, E SAVAZZI \& A SEILACHER (1982) Adaptional strategies of bivalves living as infaunal secondary soft bottom dwellers. Neues Jahrbuch für Geologie und Paläontologie, Abhandlungen 164: 229-244

CLAPPERTON CM (1994) The quaternary glaciations of Chile: a review. Revista Chilena de Historia Natural 67: 369-383.

COLLIN R (2003a) The utility of morphological characters in gastropod phylogenitics: an example from the Calyptraidae. Biological Journal of the Linnean Society 78: 541-593.

COLLIN R (2003b) Phylogenetic relationships among calyptraeid gastropods and their implications for the biogeography of marine speciation. Systematic Biology 52: 618-640.

CURREY JD \& RN HUGHES (1982) Strength of the Dogwhelk Nucella lapillus and the Winkle Littorina littorea from different habitats. Journal of Animal Ecology 51: 47-56

DALBY JE (1997) Reproductive and electrophoretic evidence for genetic maintenance of dimorphismm in the ascidian Pyura stolonifera near Melbourne, Australia. Ophelia 47: 227-243.

DEVRIES TJ (1995) Concholepas Lamarck, 1801 (Neogastropoda: Muricoidea): a Neogene genus native to South America. The Veliger 38: 284-297.

DEVRIES TJ (2000) Two New Neogene species and the Evolution of labral Teeth in Concholepas Lamarck, 1801 (Neogastropoda: Muricoidea). The Veliger 43: 43-50.

DISALVO LH (1988) Observations on the larval and postmetamorphic life of Concholepas concholepas (Bruguière, 1789) in laboratory culture. The Veliger 30: 358-368.

DUBOIS R, JC CASTILLA \& R CACCIOLATTO (1980) Sublitoral observations of behavior in the Chilean "loco" Concholepas concholepas (Mollusca: Gastropoda: Muricidae). The Veliger 23: 83-92.

DURÁN RL \& JC CASTILLA (1989) Variation and persistence of middle rocky intertidal community of Central Chile with and without human harvesting. Marine Biology 103: 555-562.

DONALD KM, YM KENNED \& HG SPENCER (2005) Cladogenesis as the result of long-distance rafting events in south pacific topshells (Gastropoda, Trochidae). Evolution 59: 1701-1711.

EXCOFFIER L, G LAVAL \& S SCHNEIDER (2005) Arlequin (version 3.0): an integrated software package for population genetics data analysis. Evolutionary Bioinformatics Online 1: 47-50.

FRASSINETTI D \& V COVACEVICH (1981) Architectonicidae en la Formación Navidad, Mioceno, Chile central, parte I. Helicinae (Mollusca: Gastropoda). Revista Geológica de Chile 13-14: 35-47.

FRASSINETTI D \& V COVACEVICH (1982) Architectonicidae en la Formación Navidad, Mioceno, Chile Central, parte III. Architectonicinae. Boletín del Museo Nacional de Historia Natural (Chile) 39: 101-109.

FELSENSTEIN J (1985) Confidence limits on phylogenies: an approach using the bootstrap. Evolution 39: 783-791.

FILATOV DA (2002) ProSeq: software for preparation and evolutionary analysis of DNA sequence datasets. Molecular Ecology Notes 2: 621-624.

FOLMER O, M BLACK, W HOEH, R LUTZ \& R VRIJENHOEK (1994) DNA primers for amplification of mitochondrial cytochrome C oxidase subunit I from diverse metozoan invertebrates. Molecular Marine Biology and Biotechnology 3: 294-299.

GALLARDO MH \& J CARRASCO (1996) Genetic cohesiveness among populations of $C$. concholepas (Gastropoda: Muricidae) in southern Chile. Journal of Experimental Marine Biology and Ecology 197:237-249.

GUÍÑEZ R, M GÓMEZ \& JC CASTILLA (1992) Diferenciación genética poblacional en $C$. concholepas (Brugière, 1789) (Gastropoda, Muricidae) en su área de distribución centro-norte. Biología Pesquera (Chile) 21: 31-41.

GRANGE LJ (2005) Reproductive success in Antarctic marine invertebrates. PhD Thesis, Faculty of Engineering Science and Mathematics, University of Southampton, Southampton, United Kingdom. 364 pp. http://eprints.soton.ac.uk/41355/ 
GROVES LT \& SN NIELSEN (2003) A new Late Miocene Zonaria (Gastropoda: Cypraeidae) from Central Chile. The Veliger 46: 351-354

HEDGECOCK D (1994) Does variance in reproductive success limit effective population sizes of marine organisms? In: Beaumont AR (ed) Genetics and evolution of aquatic organisms: 122-134. Chapman \& Hall, London, United Kingdom.

HELLBERG ME, RS BURTON, JE NEIGEL \& S PALUMBI (2002) Genetic assessment of connectivity among marine populations. Bulletin of Marine Science 70: 273-290.

HERM D (1969) Marines Pliozan und Pleistozan in Nord un Mittel-Chile unter besonderer Berucksichtigung der Entwicklung der Mollusken-faunen. Zitteliana 2: $1-159$.

IBARAKI M (1997) Closing of the Central American seaway and Neogene coastal upwelling along the Pacific coast of South America. Tectonophysics 281: 99-104

INO T (1935) Shell variation of Cellana toreuma (Reeve) in relation to the environment. Bulletin of the Japanese Society of Scientific Fisheries 4: 31-36.

JACOBS DK, TA HANEY \& KD LOUIE (2004) Genes, diversity and geologic process of the Pacific coast. Annual Review of Earth \& Planetery Science 32: 601-652.

JANSON K (1982) Genetic and environmental effects on the growth rate of Littorina saxatilis. Marine Biology 69: 73-78.

JANSON K (1983) Selection and migration in two distinct phenotypes of Littorina saxatilis in Sweden. Oecologia 59: 58-61.

JANSON K \& RD WARD (1985) The taxonomic status of Littorina tenebrosa Montagu as assessed by morphological and genetic analyses. Journal of Conchology 32: 9-15.

JOHANNESSON K \& B JOHANNESSON (1990) Genetic variation within Littorina saxatilis (Olivi) and Littorina neglecta Bean: is L. neglecta a good species? Hydrobiologia 193: 89-97.

JOHANNESSON K, B JOHANNESSON \& E ROLANÁLVAREZ (1993) Morphological differentiation and genetic cohesiveness over a microenvironmental gradient in the marine snail Littorina saxatilis. Evolution 47: 1770-1787.

JERARDINO A, JC CASTILLA, JM RAMÍREZ \& N HERMOSILLA (1992) Early coastal subsistence patterns in central Chile: s systematic study of the marine-invertebrate fauna from the site of Curaumilla-1. Latin American Antiquity 3: 43-62.

JOLLY MT, F VIARD, F GENTIL, E THIÉBAUT \& D JOLLIVET (2006) Comparative phylogeography of two coastal polychaete tubeworms in the north east Atlantic supports shared history and vicariant events. Molecular Ecology 15: 1841-1855.

KIMURA M (1981) Estimation of evolutionary distances between homologous nucleotide sequences. Proceedings of the National Academy of Sciences USA 78: 454-458

KENSLEY B (1985) The fossil occurrence in southern Africa of the South American intertidal molluscs Concholepas concholepas. Annals South African Museum 97: 1-7.

KOOL SP (1993) Phylogenetic analysis of the Rapaninae (Neogastropoda: Muricidae). Malacologia 35: 155259.

LAMBIOTTE M (1975) Le genre Concholepas J.B. Lamarck, 1801. Informacionts de la Societé Belge de Malacologie Serie 4: 37-46.
LAWVER LA \& LM GAHAGAN (2003) Evolution of Cenozoic seaways in the circum-Antarctic region. Palaeogeography, Palaeoclimatology \& Palaeoecology 198: 11-38.

LEIVA G \& JC CASTILLA (2002) A review of the world gastropod fishery: evolution of catches, management and the Chilean experience. Reviews in Fish Biology and Fisheries 11: 283-300.

LOUBERE P, M RICHAUD, Z LIU \& F MEKIK (2003) Oceanic conditions in the eastern equatorial Pacific during the onset of ENSO in the Holocene. Quaternary Research 60: 142-148.

MARKO PB \& GJ VERMEIJ (1999) Molecular phylogenetics and the evolution of labral spines among eastern Pacific ocenebrine gastropods. Molecular Phylogenetics \& Evolution 13: 275-288.

MANRÍQUEZ PH \& JC CASTILLA (2001) The significance of central Chile marine protected areas as seeding grounds for the gastropod Concholepas concholepas (Bruguière, 1789). Marine Ecology Progress Series 215: 201-211.

MANRÍQUEZ PH, SA NAVARRETE, A ROSSON \& JC CASTILLA (2004) Settlement of the gastropod Concholepas concholepas on shells of conspecific adults. Journal of the Marine Biological Association (United Kingdom) 84: 651-658

MARTÍNEZ-PARDO R (1990) Major Neogene events of the southeastern Pacific: the Chilean and Peruvian record. Palaeogeography, Palaeoclimatology \& Palaeoecology 77: 263-278.

MOLINET C, A AREVALO, MT GONZÁLEZ, CA MORENO, J ARATA \& E NIKLITSCHEK (2005) Patrones de distribución de larvas y asentamiento de Concholepas concholepas (Bruguière, 1789) (Gastropoda, Muricidae) en fiordos y canales del sur de Chile. Revista Chilena de Historia Natural 78: 409-423.

MORENO CA, KM LUNECKE \& MI LÉPEZ (1986) The response of an intertidal Concholepas concholepas (Gastropoda) population to protection from man in southern Chile and the effects on benthic sessile assemblages. Oikos 46: 359-364.

MORENO CA, G ASENCIO \& S IBÁÑEZ (1993) Patrones de asentamiento de Concholepas concholepas (Mollusca: Muricidae) en la zona intermareal rocosa de Valdivia, Chile. Revista Chilena de Historia Natural 66: 93-101.

MOY CM, GO SELTZER, DT RODBELL \& DM ANDERSON (2002) Variability of El Niño/ Southern Oscillation activity at millennial timescales during the Holocene epoch. Nature 420: $162-165$

NIELSEN SN (2004) The genus Olivancillaria (Gastropoda, Olividae) in the Miocene of Chile: rediscovery of a senior synonym and description of a new species. The Nautilus 118: 88-92.

NIELSEN SN (2005) Cenozoic Strombidae, Aporrhaidae, and Struthiolariidae (Gastropoda: Stromboidea) from Chile: their significance to the interpretation of southeast Pacific biogeography and Climate. Journal of Paleontology 79: 1120-1130.

NISHIMURA S (2002) Topics on Neogene evolution of Pacific Ocean gateways, a summary of the IGCP355. Revista Mexicana de Ciencias Geológicas 19: 271-273

O‘FOIGHIL D, BA MARSHALL, TJ HILBISH \& MA PINO (1999) Trans-pacific range extension rafting is inferred for the flat oyster Ostrea chilensis. Biological Bulletin 196: 122-126.

ORTLIEB L (1995) Paleoclimas cuaternarios en el norte 
grande de Chile. In: Argollo J \& PH Mourguiart (eds) Cambios cuaternarios en América del Sur: 225-246. Editorial Universitaria, Santiago, Chile.

PAINE RT \& TH SUCHANEK (1983) Convergence of ecological processes between independently evolved competitive dominants: a tunicate-mussel comparison. Evolution 37: 821-831.

PALMER AR (1985) Quantum changes in gastropod shell morphology need not reflect speciation. Evolution 39: 699-705.

PALMER AR (1990) Effect of crab effluent and scent of damaged conspecifies on feeding, growth and shell morphology of the Atlantic dogwhelk Nucella lapillus (L.). Hydrobiologia 193: 155-182.

PEQUEÑO G \& S SÁEZ (2000) Los peces litorales del archipiélago de Juan Fernández (Chile): endemismo y relaciones ictiogeográficas. Investigaciones Marinas (Chile) 28: 27-37

POULIN E, AT PALMA, G LEIVA, E HERNÁNDEZ, P MARTÍNEZ, SA NAVARRETE \& JC CASTILLA (2002a) Temporal and spatial variation in the distribution of epineustonic competent larvae of Concholepas concholepas (Gastropoda: Muricidae) in the central coast of Chile. Marine Ecology Progress Series 229: 95-104.

POULIN E, AT PALMA, G LEIVA, D NARVAEZ, R PACHECO, SA NAVARRETE \& JC CASTILLA (2002b) Avoiding offshore transport of competent larvae during upwelling events: the case of the gastropod Concholepas concholepas in central Chile. Limnology and Oceanography 47: 12481255.

PONDER WO \& DR LINDBERG (1997) Towards a phylogeny of gastropod mollusks: an analysis using morphological characters. Zoological Journal of the Linnean Society 119: 83-265.

POSADA D \& KA CRANDALL (1998) ModelTest: testing the model of DNA substitution. Bioinformatics 14: 817-818.

POWER ME, D TILMAN, JA ESTES, BA MENGE, W BOND, LS MILLS, G DAILY, JC CASTILLA, J LUBCHENCO \& RT PAINE (1996) Challenges in the quest for keystone. BioScience 46: 609-620.

RICHARDSON CA \& R SEED (1990) Predictions of mussel (Mytilus edulis) biomass on an offshore platform from single population samples. Biofouling 2: 289-297.

RIVADENEIRA M (2005) Macroecología evolutiva de los bivalvos marinos de la costa pacífica de Sudamérica. Tesis doctoral, Facultad de Ciencias Biológicas, Programa de doctorado en Ciencias Biológicas, mención Ecología, Pontificia Universidad Católica de Chile, Santiago Chile. 76 $\mathrm{pp}$.

SEGAL E (1956) Adaptive difference in water-holding capacity in an intertidal gastropod. Ecology 37: 174-178

SILVA N \& H SIEVERS (1973) Condiciones oceanográficas de primavera y otoño de las aguas circundantes a las islas Robinson Crusoe y Santa Clara. Investigaciones Marinas (Chile) 4: 158-179.

SCHANDER C \& P SUNDBERG (2001) Useful characters in gastropod phylogeny: soft information or hard facts? Systematic Biology 50: 136-141.

SOKAL RR \& FJ ROHLF (1981) Biometry. Second edition. W. H. Freeman, San Francisco, California, USA. Xx pp.

STANLEY S (1978) Chronospecies' longevities, the origin of genera, and the punctuational model of evolution. Paleobiology 4: 26-40.
STEARNS SC (1989) The evolutionary significance of phenotypic plasticity. BioScience 39: 436-445.

STOTZ WB, DA LANCELLOTTI, DJ MARTÍNEZ, P DE AMESTI \& E PÉREZ (1991) Variación temporal y espacial del registro de juveniles recién asentados de Concholepas concholepas (Bruguiere, 789), en el intermareal rocoso de la IV Región, Chile. Revista de Biología Marina (Chile) 26: 351-361.

STOTZ WB, SA GONZÁlEZ, L CAILLAUX \& J ABURTO (2003) Quantitative evaluation of the diet and feeding behaviour of the carivorous gastropod Concholepas concholepas (Bruguiere, 1789) (Muricidae) in subtidal habitats in the southeastern Pacific upwelling system. Journal of Shellfish Research 22: 147-164.

STUARDO J (1979) Sobre la clasificación, distribución y variación de Concholepas concholepas (Bruguiere, 1789): un estudio de taxonomía Beta. Biología Pesquera (Chile) 12: 5-38.

SWOFFORD DL (2002) PAUP*, Phylogenetic analysis using parsimony (*and other methods). Release 4. Sinauer Associates, Sunderland, Massachusetts, USA.

THIEL M \& HAYE PA (2006) The ecology of rafting in the marine environment. III. Biogeographical and evolutionary consequences. Oceanography and Marine Biology: an Annual Review 44: 323-429.

THOMPSON JD, TJ GIBSON, F PLEWNIAK, F JEANMOUGIN \& DG HIGGINS (1997) The Clustal X windows interface: flexible strategies for multiple sequence alignment aided by quality analysis tools. Nucleic Acids Research 24: 48764882.

TRUSSELL GC (1997) Phenotypic plasticity in the foot size of an intertidal snail. Ecology 78: 1033-1048.

TSUCHI R (2002) Neogene evolution of surface marine climate in the Pacific and notes on related events. Revista Mexicana de Ciencias Geológicas 19: 260270.

UTHICKE S \& JAH BENZIE (2003) Gene flow and population history in high dispersal marine invertebrates: mitochondrial DNA analysis of Holothuria nobilis (Echinodermata: Holothuroidea) populations from the Indo-Pacific. Molecular Ecology 12: 2635-2648.

VÁSQUEZ JA \& B SANTELICES (1984) Comunidades de macroinvertebrados en discos adhesivos de Lessonia nigrescens Bory (Phaeophyta) in central Chile. Revista Chilena de Historia Natural 57: 131-154.

VERMEIJ GJ (1973) Morphological pattern in highintertidal gastropods: adaptive strategies and their limitations. Marine Biology 20: 319-346.

VIA S \& R LANDE (1985). Genotype-environment interaction and the evolution of phenotypic plasticity. Evolution 39: 505-523.

VERMEIJ GJ (1987) The dispersal barrier in the tropical Pacific: implications for molluscan speciation and extinction. Evolution 41: 1046-1058.

VERMEIJ GJ (1998) New genera of Cenozoic muricid gastropods, with comments on the mode of formation of the labral tooth. Journal of Paleontology 72: 855-864.

VERMEIJ GJ \& SJ CARLSON (2000) The muricid gastropod subfamily Rapaninae: phylogeny and ecological history. Paleobiology 26: 19-46.

VILLAGRÁN C (1995) El Cuaternario en Chile: evidencias de cambio climático. In: Argollo J \& PH Mourguiart (eds) Cambios cuaternarios en América del Sur: 191-214. Editorial Universitaria, Santiago, Chile. 
VOKES EH (1972) Notes of the fauna of the Chipola Formation-7. On the occurrence of the genus Concholepas (Gastropoda: Thaididae), with the description of a new species. Tulane Studies in Geology and Paaleontology 72: 855-864.

WATERS JM (2007) Driven by the West Wind Drift? A synthesis of southern temperate marine biogeography, with new directions for dispersalism. Journal of Biogeography Online.

WEIR BS \& CC COCKERHAM (1984) Estimating Fstatistics for the analysis of population structure. Evolution 38: 1358-1370.

ZACHOS J, M PAGANI, L SLOAN, E THOMAS \& K

Associate Editor: Elie Poulin

Received June 5, 2007; accepted January 29, 2008
BILLUPS (2001) Trends, rhythms, and aberrations in global climate 65 MA to present. Science 292: 686-693.

ZANE L, S MARCATO, L BARGELLONI, E BORTOLOTTO, C PAPETTI, M SIMONATO, V VAROTTO \& T PATARNELLO (2006) Demographic history and population structure of the Antarctic silverfish Pleuragramma antarcticum. Molecular Ecology 15: 4499-4511.

ZINMEISTER WJ (1978) Effect of formation of the West antartic ice sheet on shalow-water marine faunas of Chile. Antarctic Journal USA 13: 2526. 